\title{
Relationship between Protein Intake and Nitrogen Balance in Obese Patients on Low Energy Diet
}

\author{
Yuriko OI, Toyoko OKUDA, Hideo KoISHI, ${ }^{1}$ \\ Hideki KoH, Masako WAKI, Miki KURATA, \\ and Seiki NAMBU ${ }^{2}$ \\ ${ }^{1}$ Department of Food and Nutrition, Faculty of the Science of Living, \\ Osaka City University, Sugimoto, Sumiyoshi-ku, Osaka 558, Japan \\ ${ }^{2}$ Department of Clinical Nutrition, National Cardiovascular Center, \\ Fujishirodai, Suita, Osaka 565, Japan
}

(Received December 10, 1986)

\begin{abstract}
Summary The effect of nitrogen intake on nitrogen balance was studied in six obese patients receiving low energy diets. They were given a control diet containing 2,000 kcal of energy and $80 \mathrm{~g}$ of protein for the first ten days. Then they were given Diet A with $1,100 \mathrm{kcal}$ of energy and $70 \mathrm{~g}$ of protein for the next 2 weeks, followed by Diet B with 1,100 kcal of energy and $50 \mathrm{~g}$ of protein for 2 weeks. The relationship between nitrogen intake $(X, \mathrm{mg} / \mathrm{kg})$ and nitrogen balance $(Y, \mathrm{mg} / \mathrm{kg})$ during the low energy diet periods was statistically significant, with $Y=0.388 X-60.32(\mathrm{SD}=$ 17.71, $r=+0.67, n=11, p<0.05)$. The nitrogen and protein requirements were estimated from this equation to be $201.1 \mathrm{mg} / \mathrm{kg}$ and $1.26 \mathrm{~g} / \mathrm{kg}$, respectively. In our experiment, the nitrogen balance in obese patients was well maintained although total energy was reduced to $1,100 \mathrm{kcal} / \mathrm{day}$ in Diet A. It is suggested that protein quantity in the diets should be taken into account when a low energy diet is used for the treatment of obesity. Key Words obese patients, protein metabolism, energy restriction, low energy diet, nitrogen balance, maintenance requirement (for equilibrium), protein requirement
\end{abstract}

In humans, the protein content of energy-restricted diets greatly influences the protein metabolism of the whole body (1-7). A protein-sparing modified fast (2-6) has been used in adults as a method for weight reduction wherein nitrogen balance is maintained. Garlick et al.(1) studied the nitrogen flux, protein synthesis, and breakdown using $\left[{ }^{15} \mathrm{~N}\right]$ glycine in obese subjects eating an energy-restricted diet with various protein levels. They found that if protein intake was adequate $(50 \mathrm{~g} / \mathrm{day})$, whole-body protein synthesis was unchanged when the energy intake was decreased

${ }^{1}$ 尾井百合子, 奥田豊子, 小石秀夫, ${ }^{2}$ 洪 秀樹, 脇 昌子, 鞍田三貴, 南部征喜 
from 8.0 to $2.1 \mathrm{MJ} /$ day. However, on a low energy, protein-free diet, synthesis fell to about $60 \%$ of the baseline value. The level of protein intake was important for the maintenance of whole-body protein turnover during energy restriction. It is generally believed that the effects of energy and protein restriction are complex, depending on the total amounts of protein and energy provided and on body reserves (7-12). The present study was done to examine the effect of protein levels in energy-restricted diets on the nitrogen balance of obese patients. Furthermore, we discussed the relationship between protein intake and nitrogen balance in obese patients on low energy diets.

\section{METHODS}

Subjects. The characteristics of the obese patients, three men and three women, are described in Table 1. Their obesity degree, in terms of percentage of ideal body weight, ranged from $120 \%$ to $190 \%$. All patients were hospitalized during the study and kept on the hospital diet. One patient (Case 4) decided to leave the hospital after the first part of the experiment. The nature and purpose of the study were explained to each subject, and informed consent was obtained from all.

Experimental diets. The composition of the diets is shown in Table 2. First, patients were given the control diet, which contained 2,000 kcal of energy and $80 \mathrm{~g}$ of protein, for 10 days. Two low energy diets for 2 weeks each followed immediately. Diet A contained $1,100 \mathrm{kcal}$ of energy and $70 \mathrm{~g}$ of protein and Diet B contained $1,100 \mathrm{kcal}$ of energy and $50 \mathrm{~g}$ of protein. Meals were supervised by investigation-unit staff (nutritionists, nurses, etc.) and complete consumption of the food was checked. Samples of the diets were lyophilized and the nitrogen contents were

Table 1. Characteristics of obese subjects.

\begin{tabular}{|c|c|c|c|c|c|c|c|}
\hline \multirow{2}{*}{ Case no. } & \multirow{2}{*}{ Sex } & \multirow{2}{*}{ Age } & \multirow{2}{*}{$\begin{array}{l}\text { Height } \\
(\mathrm{cm})\end{array}$} & \multirow{2}{*}{$\begin{array}{l}\text { B.W. } \\
(\mathrm{kg})\end{array}$} & \multirow{2}{*}{$\begin{array}{c}\text { Ideal B.W. }{ }^{\mathrm{a}} \\
(\%)\end{array}$} & \multicolumn{2}{|c|}{ B.W. loss $(\mathrm{kg})^{\mathrm{b}}$} \\
\hline & & & & & & Diet A & Diet B \\
\hline 1 & M & 59 & 161.5 & 66.5 & 120.0 & -3.0 & -1.2 \\
\hline 2 & M & 59 & 156.0 & 64.0 & 127.0 & -2.0 & -1.2 \\
\hline 3 & M & 51 & 166.0 & 75.0 & 126.3 & -2.5 & -1.7 \\
\hline 4 & $\mathrm{~F}$ & 59 & 149.5 & 55.5 & 124.6 & -2.5 & - \\
\hline 5 & $\mathrm{~F}$ & 51 & 150.8 & 87.0 & 190.4 & -1.5 & -1.7 \\
\hline 6 & $\mathrm{~F}$ & 52 & 158.5 & 84.7 & 160.9 & -2.3 & -1.2 \\
\hline Mean \pm SD & & & & & & $-2.3 \pm 0.5$ & $-1.4 \pm 0.3^{*}$ \\
\hline
\end{tabular}

${ }^{\mathrm{a}}$ Ideal B.W. $(\mathrm{kg})$ : (height -100$) \times 0.9 .{ }^{\mathrm{b}}$ Body weight loss means the results on two low energy diets for 2 weeks each; subjects were given Diet A with 1,100 kcal of energy and $70 \mathrm{~g}$ of protein for the first 2 weeks, followed by Diet B with $1,100 \mathrm{kcal}$ of energy and $50 \mathrm{~g}$ of protein for 2 weeks. * Significantly different from Diet A $(p<0.05)$. 
Table 2. Diet compositions (g).

\begin{tabular}{lrrr}
\hline & Control & Diet A & Diet B \\
\hline Steamed rice & 540 & 220 & 360 \\
Bread & 80 & 40 & 40 \\
Wheat & 10 & - & - \\
Potatoes & 100 & - & 50 \\
Fish & 100 & 100 & 50 \\
Meat & 100 & 500 & 25 \\
Egg & 50 & 100 & 50 \\
Soy products & 100 & 180 & - \\
Milk & 200 & 5 & 5 \\
Oil & 20 & 300 & 100 \\
Vegetables & 350 & 100 & 1,100 \\
Fruit & 100 & 1,100 & 50 \\
Energy (kcal) & 2,000 & 70 & 32 \\
Protein & 80 & 32 & 205 \\
Fat & 50 & 125 & \\
Carbohydrates & 285 & & \\
\hline
\end{tabular}

analyzed. Energy intakes were estimated from the portions ingested using standard food tables.

Experiment. The study of nitrogen balance started on day 6 for the control diet and on day 10 for Diets A and B, and continued for 3 days each. Twenty-fourhour urine was collected for the assay of daily nitrogen excretion throughout the balance study. As a fecal marker, $1 \mathrm{~g}$ of carmine was given at breakfast on the first day of each balance study and on the day after the balance study ended. Feces were collected for the three days of the balance study, lyophilized. Their nitrogen contents were then analyzed. The nitrogen contents of the food, urine, and fecal samples were analyzed by the semi-micro Kjeldahl method. Blood samples were drawn before breakfast from the antecubital vein. The total protein, albumin, urea nitrogen, creatinine, triglycerides, and total cholesterol of the sera were analyzed using an auto-analyzer (Toshiba-TBA type 80-S, Toshiba Medical Co.), and HDLcholesterol was assayed by the method of precipitation (13).

Data were analyzed by Student's $t$-test, and $p$ values of less than 0.05 were considered to be statistically significant.

\section{RESULTS}

\section{Body weight}

The mean weight loss was $2.3 \pm 0.5 \mathrm{~kg}$ on Diet $\mathrm{A}$, and $1.4 \pm 0.3 \mathrm{~kg}$ on Diet $\mathrm{B}$, which was $3.6 \pm 0.5 \mathrm{~kg}$ over 4 weeks. The loss during Diet B was significantly less (Table 1). 
Table 3. Nitrogen balance ( $\mathrm{mg} \mathrm{N} / \mathrm{kg} /$ day).

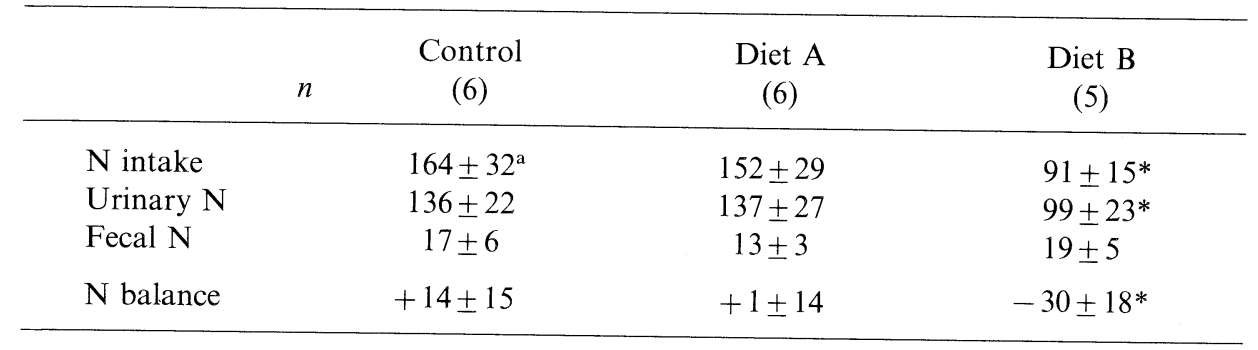

${ }^{a}$ Values are means $\pm \mathrm{SD} .{ }^{*}$ Significantly different from the control group $(p<0.05)$.

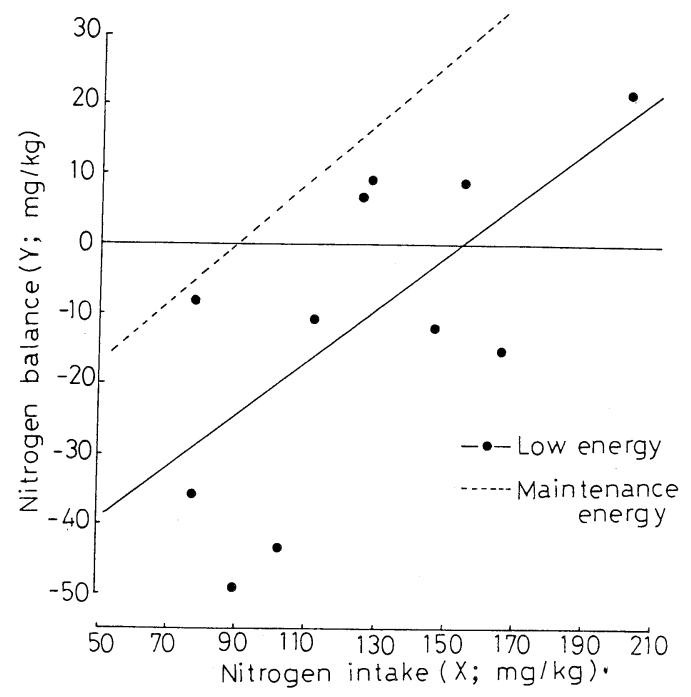

Fig. 1. Relationship between nitrogen intake and nitrogen balance. Points are mean values for a three-day balance study for individual subjects receiving the low energy diet. The line for maintenance energy is cited from the data of Inoue et al. (8).

\section{Nitrogen balance}

The nitrogen balance in the respective diet periods is shown in Table 3 . The control diet and Diet A were similar in intakes of dietary nitrogen, but the intake during the Diet B period was lower. Nitrogen excretion in the urine was similar on the control diet and Diet A, although that in the Diet B period was significantly lower. There were no significant differences in fecal nitrogen excretion. The nitrogen balance on the control diet and during the Diet A period approximately maintained on equilibrium but a marked negative balance was shown on Diet $B$.

\section{Nitrogen requirement}

The relationship between nitrogen intake and nitrogen balance is shown in Fig. 
Table 4. Nitrogen and protein requirements.

\begin{tabular}{|c|c|c|c|}
\hline & \multicolumn{2}{|c|}{ Low energy } & \multirow{2}{*}{$\frac{\text { Maintenance energy }^{\mathrm{a}}}{(11)}$} \\
\hline$n$ & $\begin{array}{l}\text { Diet A } \\
\text { (6) }\end{array}$ & $\begin{array}{l}\text { Diet B } \\
(5)\end{array}$ & \\
\hline $\begin{array}{l}\text { Energy intake } \\
\quad(\mathrm{kcal} / \mathrm{kg})\end{array}$ & \multicolumn{2}{|c|}{$15 \pm 3^{b}$} & $45 \pm 2$ \\
\hline $\begin{array}{l}\text { Nitrogen intake } \\
(\mathrm{mg} / \mathrm{kg})\end{array}$ & $152 \pm 29$ & $91 \pm 15$ & \\
\hline $\begin{array}{l}\text { Equation of } \\
\text { regression line }\end{array}$ & $Y=0.388 \lambda$ & $.32 \pm 17.71$ & $Y=0.411 X-37.03 \pm 5.80$ \\
\hline Correlation & & & +0.78 \\
\hline Significance & & & $p<0.01$ \\
\hline $\begin{array}{l}\text { Maintenance } \\
\text { requirement }(\mathrm{mg} / \mathrm{kg})^{\mathrm{d}}\end{array}$ & 155 & 5.6 & $90.1 \pm 14.1^{*}$ \\
\hline \multicolumn{4}{|l|}{ Requirements for: } \\
\hline Nitrogen $(\mathrm{mg} / \mathrm{kg})^{\mathrm{e}}$ & & & 104.2 \\
\hline Protein $(\mathrm{g} / \mathrm{kg})^{\mathrm{e}}$ & & & 0.65 \\
\hline
\end{tabular}

${ }^{a}$ Cited from Inoue et al. (8). ${ }^{\mathrm{b}}$ Values are means $\pm \mathrm{SD}$. ${ }^{\mathrm{c}}$ The equations were obtained by plotting of the nitrogen balance $(Y, \mathrm{mg} / \mathrm{kg})$ against the intake $(X, \mathrm{mg} / \mathrm{kg}) .{ }^{\mathrm{d}} \mathrm{N}$ needed for equilibrium was calculated from the equation with $Y$ equal to zero. ${ }^{\mathrm{e}}$ Value of one standard deviation above the average maintenance requirement is taken as the requirement (coefficient of variation for maintenance requirement was $29.32 \%, 45.6 / 155.5$. Thus, values of $201.1,155.5,1.29$, were considered as the requirement). ${ }^{*}$ Significant different from low energy diets at $p<0.05$.

Table 5. Serum status.

\begin{tabular}{lrccr}
\hline & & $\begin{array}{c}\text { Control } \\
(6)\end{array}$ & $\begin{array}{c}\text { Diet A } \\
(6)\end{array}$ & $\begin{array}{c}\text { Diet B } \\
(5)\end{array}$ \\
\hline Total protein & $(\mathrm{g} / 100 \mathrm{ml})$ & $6.6 \pm 0.4^{\mathrm{a}}$ & $6.3 \pm 0.3$ & $6.5 \pm 0.4$ \\
Albumin & $(\mathrm{g} / 100 \mathrm{ml})$ & $4.1 \pm 0.3$ & $4.0 \pm 0.2$ & $4.1 \pm 0.4$ \\
Urea nitrogen & $(\mathrm{mg} / 100 \mathrm{ml})$ & $14.3 \pm 1.4$ & $14.8 \pm 2.3$ & $11.8 \pm 1.9$ \\
Creatinine & $(\mathrm{mg} / 100 \mathrm{ml})$ & $0.9 \pm 0.2$ & $1.0 \pm 0.2$ & $1.2 \pm 0.2$ \\
Triglycerides & $(\mathrm{mg} / 100 \mathrm{ml})$ & $143 \pm 44$ & $104 \pm 42$ & $115 \pm 26$ \\
Total cholesterol & $(\mathrm{mg} / 100 \mathrm{ml})$ & $210 \pm 9$ & $200 \pm 26$ & $208 \pm 26$ \\
HDL cholesterol & $(\mathrm{mg} / 100 \mathrm{ml})$ & $35 \pm 6$ & $40 \pm 8$ & $35 \pm 18$ \\
\hline
\end{tabular}

${ }^{a}$ Values are means \pm SD.

1. The nitrogen intake correlated with the nitrogen balance on the low energy diets $(r=0.67, p<0.05)$. The equation obtained was $Y=0.388 X-60.32 \pm 17.71$, where $Y$ is the nitrogen balance $(\mathrm{mg} / \mathrm{kg})$ and $X$ is the nitrogen intake $(\mathrm{mg} / \mathrm{kg})$. From this

Vol. 33, No. 3, 1987 
equation, the maintenance $\mathrm{N}$ requirement was calculated as $155.5 \pm 45.6 \mathrm{mg} / \mathrm{kg}$. Table 4 shows the nitrogen and protein requirements. The nitrogen requirement during low energy intake was calculated as $201.1 \mathrm{mg} / \mathrm{kg}(1.26 \mathrm{~g}$ protein $/ \mathrm{kg})$ by taking the value of one SD above the average maintenance requirement.

\section{Serum status}

The serum status is shown in Table 5. There were no significant differences during each diet period in the total protein and albumin of the serum. Urea nitrogen during the control diet and Diet A periods was comparable, but it tended to be lower during the Diet B period. During the Diets A and B periods, triglycerides tended to be lower than during the control diet period. There were no changes in total cholesterol and HDL cholesterol. Thus, changes in the protein and energy intakes had no marked effect.

\section{DISCUSSION}

The effects of the restriction of energy and protein are complex and depend on the total amount of protein and energy provided, body reserves, and the length of the restriction (12). Bistrian et al. (14) suggested that endogenous fat (deposit fat) is used as the energy source to make up deficiency during energy restriction in obese subjects. Therefore, it seems that in our experiment body weight loss involved to some extent the deposit fat. It is probable that decreases in body fat were directly reflected on the weight loss, since the nitrogen balance was approximately at equilibrium on Diet A. But the weight losses were not necessarily caused by loss of body fat, since the nitrogen balance was markedly negative on Diet B; some protein in the body might have been broken down as well. For obese patients, the composition of Diet A was better than that of Diet B for the treatment of obesity by restriction of energy intake $(1,100 \mathrm{kcal} /$ day).

In our study, there was a correlation between nitrogen intake and nitrogen balance on the low energy Diets A and B. The slope of the regression line was similar to that for the maintenance energy intake of young Japanese adults, although the energy intake of the obese patients was reduced to about one-third the maintenance energy intake (8). The protein metabolism in healthy adults and in obese patients may differ in some way, but it is thought that because the slope of the regression line was similar, the protein efficiency was similar. On the other hand, the regression line of obese patients was considerably lower than that of the maintenance energy intake young Japanese adults, suggesting that the nitrogen balance tended to be negative during low energy diets. The $\mathrm{N}$ needed for equilibrium (maintenance requirement) in this experiment was similar to the nitrogen intake on Diet A. The maintenance requirement for obese patients was significantly higher than provided in the maintenance energy intake for young Japanese adults, and the protein requirement in patients was about twice that for the maintenance energy intake of young adults. Our data indicated that the protein level of Diet A was 
needed to maintain the nitrogen balance when energy intake was restricted to $1,100 \mathrm{kcal}$. However it was not clear whether nitrogen balance would be maintained if subjects of normal weight were restricted in energy as on Diet A. The relationship between the intakes of energy and protein in obese subjects seems different from that in subjects on normal weight (15).

Inoue et al. $(8)$ examined the effects of maintenance $(45 \pm 2 \mathrm{kcal} / \mathrm{kg})$ or an excess of energy intake $(57 \pm 2 \mathrm{kcal} / \mathrm{kg})$ on the nitrogen balance in low protein diets. Excess energy supply resulted in increased availability of ingested protein, with a reduction in the amount of protein required. Kishi et al. (16) examined the effect of marginal energy intake on the protein requirement in young Japanese adults, and suggested that the improvement in $\mathrm{N}$ balance is greater when energy is added to an energy-deficient diet and that energy has a marked effect on the protein requirement. Calloway (12) showed that energy intake has a greater effect on $\mathrm{N}$ balance than protein intake in the marginally adequate intake range. Her investigations provided estimates of the minimum $\mathrm{N}$ needed to maintain the apparent $\mathrm{N}$ equilibrium (dietary-fecal-urinary $\mathrm{N}$ ) of $68 \pm 15 \mathrm{mg} / \mathrm{kg}$ with $43 \pm 4 \mathrm{kcal} / \mathrm{kg}$ and $89 \pm 18 \mathrm{mg} / \mathrm{kg}$ with $40 \pm 4 \mathrm{kcal} / \mathrm{kg}$. The $\mathrm{N}$ balance fell to $-0.61 \mathrm{~g} / \mathrm{day}$ with a $15 \%$ decrease in energy intake and rose to $0.59 \mathrm{~g}$ /day with a $15 \%$ increase in energy intake.

Similar effects of energy intake on the protein requirement were found in our obese patients; the protein requirements in obese patients during low energy intake were significantly higher than those in adults of normal weight during maintenance energy intake.

In conclusion, the nitrogen balance in obese patients could be well maintained by adequate protein intake $(70 \mathrm{~g} /$ day) although total energy was reduced to $1,100 \mathrm{kcal} /$ day. Furthermore, it is suggested that protein quantity in the diets should be taken into account when a low energy diet is used for the treatment of obesity.

\section{REFERENCES}

1) Garlick, P. J., Clugston, G. A., and Waterlow, J. C. (1980): Influence of low-energy diets on whole-body protein turnover in obese subjects. Am. J. Physiol., 238 (Endcrinol. Metab. 1), E235-244.

2) Waterlow, J. C., Bistrian, B. R., Bilmazes, C., Blackburn, G. L., and Young, V. R. (1980): Whole body protein turnover, studied with ${ }^{15} \mathrm{~N}$-glycine and muscle protein breakdown in mildly obese subjects. Metabolism, 29, 575-581.

3) Pencharz, P. B., Motil, K. J., Parsons, H. G., and Duffy, B. J. (1980): The effect of an energy-restricted diet on the protein metabolism of obese adolescents: nitrogen balance and whole body nitrogen turnover. Clin. Sci., 59, 13-18.

4) Fisler, J. S., Drenick, E. J., Blumfield, D. E., and Swendseid, M. E. (1982): Nitrogen economy during very low calorie reducing diets: quality and quantity of protein. Am.J. Clin. Nutr., 35, 471-486.

5) Russel, D. M., Leiter, L. A., Whitwell, J., Marliss, E. B., and Jeejeebhoy, K. N. (1983): Skeletal muscle function during hypocalorie diets and fasting: a comparison with standard nutritional assessment parameters. Am. J. Clin. Nutr., 37, 133-138.

Vol. 33, No. 3, 1987 
6) Brown, M. R., Klish, W. J., Hollander, J., Campbell, M. A., and Forbes, G. B. (1983): A high protein, low calorie liquid diet in the treatment of very obese adolescents: longterm effect on lean body mass. Am. J. Clin. Nutr., 38, 20-31.

7) Fisler, J. S., Kaptein, E. M., Drenick, E. J., Nicoloff, J. T., Yoshimura, N. N., and Swendseid, M. E. (1985): Metabolic and hormonal factors as predictors of nitrogen retention in obese men consuming very low caloric diets. Metabolism, 34, 101-105.

8) Inoue, G., Fujita, Y., and Niiyama, Y. (1973): Studies on protein requirements of young men fed egg protein and rice protein with excess and maintenance energy intakes. J. Nutr., 103, 1673-1687.

9) Munro, H. N., and Naismith, D. J. (1953): The influence of energy intake on protein metabolism. Biochem. J., 54, 191-197.

10) Uauy, R., Scrimshaw, N. S., Rand, W. M., and Young, V. R. (1978): Human protein requirements: Obligatory urinary and fecal nitrogen losses and the factorial estimation of protein needs in elderly males. $J$. Nutr., 108, 97-103.

11) Rosenthal, H. L., and Allison, J. B. (1951): Some effects of calorie intake on nitrogen balance in dogs. $J$. Nutr., 44, 423-431.

12) Calloway, D. H. (1975): Nitrogen balance of men with marginal intake of protein and energy. J. Nutr., 105, 914-923.

13) Kajikawa, T., Ishiki, R., Nakao, Y., Kujoh, H., Kodama, J., Nambu, S., and Yamamoto, A. (1981): Approach on the standardized of measurement of HDLcholesterol by the method of heparin-Ca ${ }^{+}$. Doumyakukouka (Atherosclerosis), 9, 393397.

14) Bistrian, B. B., Blackburn, G. L. Flatt, J. P., Sizer, J., Scrimshow, N. S., and Sherman, M. (1976): Nitrogen metabolism and insulin requirements in obese diabetic adults on a protein sparing modified fast. Diabetes, 25, 494-504.

15) Sim, A. J. W., Wolfe, B. W., Young, V. R., Clark, D., and Moore, F. D. (1979): Glucose promotes whole body protein synthesis from infused amino acids in fasting man. Lancet, i, 68-71.

16) Kishi, K., Miyatani, S., and Inoue, G. (1978): Requirement and utilization of egg protein by Japanese young men with marginal intakes of energy. J. Nutr., 108, 658-669. 